\title{
THE JEWISH ANNOTATED NEW TESTAMENT: RETROSPECT AND PROSPECTS
}

\author{
Marc Zvi Brettler and Amy-Jill Levine*
}

\begin{abstract}
The Jewish Annotated New Testament, published by Oxford University in 2011, had little precedent: this was the first time that a group of Jewish scholars wrote a commentary (with supplemental essays) on the entire New Testament. As its editors, we were attentive to how the book would be perceived by a readership that, for various reasons, might find the volume at best odd, at worst scandalous. We conceived of and edited the volume with three main audiences in mind: Christians who wanted to know more about the Jewish background of the New Testament; Jews who had little familiarity with the New Testament; and readers from any background who were curious about the New Testament in its original historical matrix. In this essay we discuss our goals in writing the commentary for these audiences, such as overturning Christian stereotypes of Jews and Judaism and Jewish stereotypes of Christians and Christianity, and showing Jewish and Christian readers a part of their intertwined history. We also discuss the book's reception, which has been largely positive in Jewish and Christian communities and classrooms, despite acerbic and even frightening reviews and blog posts by a handful of readers.
\end{abstract}

As the editors of The Jewish Annotated New Testament (JANT), published by Oxford University Press in 2011, we were attentive to how the book would be perceived by a readership that, for various reasons, might find the volume at best odd, at worst scandalous. Our venture had little precedent: this was the first time that a group of Jewish scholars convened to write a (brief) commentary on the entire New Testament, let alone to offer a collection of supplemental essays that addressed subjects ranging from the intersections of Judaism and the origins of Christianity to how Jews have understood the two main figures of the New Testament, Jesus and Paul, over the centuries.

We conceived of and edited the volume with three main audiences in mind: Christians who wanted to know more about the Jewish background of the New Testament; Jews who had little familiarity with the New Testament; and readers from any background who were curious about the New Testament in its original historical matrix. In terms of the first audience, we believe that to misunderstand Jewish practices and beliefs of the first century C.E. will necessarily result in a misunderstanding of Jesus of Nazareth and his followers; to have familiarity with this setting will help any reader better understand the contents of the New Testament.

Our goals went beyond providing basic historical information; we also sought to correct the negative stereotypes of Jews and Judaism that often, usually unintentionally, come to permeate Christian sermons and Bible studies. From our experiences in the classroom and

\footnotetext{
" Marc Brettler: Dora Golding Professor of Biblical Studies and former chair of the Department of Near Eastern and Judaic Studies at Brandeis University, USA. Email: brettler@brandeis.edu

Amy-Jill Levine: University Professor of New Testament and Jewish Studies and E. Rhodes and Leona B. Carpenter Professor of New Testament Studies at Vanderbilt University, USA. Email: amy-jill.levine@ @anderbilt.edu
} 
in churches where we have taught scholar-in-residence programs, we are aware that some Christian readers view the Jews of Jesus' day (if not through the centuries) as hypocritical, greedy, legalistic, spiritually dead, militaristic, interested in retributive violence rather than restorative justice, xenophobic, and misogynist, if not out to undermine Christianity and to rule the world. These views are, not infrequently, inculcated in Sunday school lessons and reinforced in sermons. Were the volume to become mandatory reading for all Christian clergy and religious educators, it would go a long way toward alleviating these problematic teachings.

At the same time, well aware of the openness many of our Christian friends and many churches have shown toward Jewish history and Jewish readers, we also wished to demonstrate, reciprocally, our mutual respect. In 2001, the Pontifical Biblical Commission issued a study titled, "The Jewish People and Their Sacred Scriptures in the Christian Bible." This document affirmed both that "Although the Christian reader is aware that the internal dynamism of the Old Testament finds its goal in Jesus, this is a retrospective perception whose point of departure is not in the text as such, but in the events of the New Testament proclaimed by the apostolic preaching" (II,A,6) and that "Christians can and ought to admit that the Jewish reading of the Bible is a possible one, in continuity with the Jewish Sacred Scriptures from the Second Temple period, a reading analogous to the Christian reading which developed in parallel fashion" (II,A,7). That is, it recognizes and respects Jewish interpretation of our own Scripture (the Tanakh). JANT is a response, in part, to the graciousness of this document: as the Pontifical Biblical Commission expresses a positive view of Jewish biblical interpretation, so we Jews reciprocate with a positive reading of the New Testament. Jewish interpretations of the Tanakh are not a recognized part of Catholic teaching, and the New Testament is not canonical for Jews. Mutual respect and a sense of shared history, however, make the study of each other's tradition a worthwhile, indeed essential, endeavor.

Many Jews have avoided reading the New Testament for various reasons: a concern that it would disparage Jews and Judaism; the presupposition that its texts would not only be strange but also alienating; perhaps even a fear of being seduced by the gospels. JANT, written entirely by Jews, might allow Jewish readers to find the text initially less alien, or alienating. We also wanted to show Jewish readers parts of our own history, since much of the New Testament is Jewish history: its principal figures are Jews; its imagery draws from the Scriptures of Israel; its legacy has impacted relations between Synagogue and Church for the past two millennia. We wanted as well to alert our Jewish readers to the problematic passages in the New Testament, both to provide some explanation as to what purpose they served in their original contexts and to show that most Christian readers do not move directly from a negative comment about Jewish people or practice to a negative view of Jews and Judaism. Just as reading about slavery in Egypt does not prompt Jews to hate Egyptians, and just as reading Deuteronomy does not make Jews desire to commit genocide against non-Jews in Israel, so we sought to show how Christian readers generally have their own filters that function to prevent anti-Semitism.

We also sought to correct the negative and false stereotypes that some Jewish readers have of Christians and Christianity, for we have also heard these stereotypes expressed in the classroom and in synagogue programs: that Christianity is a religion that cares only about belief and not about practice; that the ideas of a miraculous conception, resurrection from the dead, a divine manifest in different forms, an incarnate "Word," etc., make no 
sense in a first-century Jewish context; that those who believe in Jesus, then or now, are either ignorant or superstitious. And if studying the New Testament prompts Jews to learn, or relearn, the material that it cites from the Tanakh or that finds connections in rabbinic literature, so much the better.

Usually with negative and sometimes tragic effects, the New Testament and its interpretations across the past two millennia have been instrumental in how Jews have been viewed and even in how they viewed themselves. Recognition of this influence is one factor in the increasing interest Jewish scholars have shown in the New Testament. (The Talmud offers several negative references to Jesus and to his followers - references that were often removed by Christian censors - but such negative views did not prevail over the centuries, and most Jews are unaware that they ever existed.) We are not the first within the Jewish community to advocate for reading the New Testament and understanding it positively rather than polemically. Writers such as Moses Mendelssohn (1729-1786), Abraham Geiger (1810-1874), Claude Montefiore (1858-1938), Stephen Wise (1874-1949), Martin Buber (1878-1965), and Joseph Klausner (1874-1958) sought to reclaim Jesus for the Jewish tradition. Samuel Sandmel published several books on the New Testament, including the still-influential We Jews and Jesus (1965), and Hugh J. Schonfield's The Passover Plot (1965) was about as popular then, and as controversial, as Dan Brown's recent The Da Vinci Code. Today, well more than a minyan of Jews - many of them contributors to $J A N T$ - have published academic books and articles on Jesus and his followers. JANT's annotations and essays demonstrate how rabbinic, medieval, and modern Jewish interpreters have understood Jesus; the volume also annotates the New Testament in light of early Jewish sources so that readers can see both connections and novel contributions.

Even Paul has been a prominent topic among Jewish thinkers, as Daniel Langton has recently demonstrated. Baruch Spinoza (1632-1677) and R. Jacob Emden (1697-1776) commented positively on Paul, while later writers such as Heinrich Graetz (1817-1891), Kaufman Kohler (1843-1926), and Buber attributed to Paul a deformation of the more "Jewish" Jesus. This volume provides the historical context by which Paul can best be understood and so allows readers to judge him for themselves.

In relation to both Jewish and Christian readers, we were also cognizant of the need for resources for inter-religious families. For example, Christian parents concerned about their children's Jewish spouses or their Jewish grandchildren have sought a resource that would help them understand both how Judaism and Christianity are related, and how and why they separated. Similarly, Jews with Christian relatives have sought information about how to understand the Scriptures that their new family members hold as sacred.

Along with the practical needs, pedagogical interests also informed our vision of the volume. We view $J A N T$ as part of the larger genre of academically rigorous annotated Bibles, such as Oxford's New Oxford Annotated Bible (Fourth Edition). Our hopes were that JANT would find a place alongside The Jewish Study Bible not only in the church- or synagogue-based adult education program but also in the classroom. This introduces a new challenge: how to convince young adults of all religious persuasions, and those of no religious background or allegiance at all, that the New Testament is a foundational book that should be read.

We do think that everyone ought to know the material in the New Testament, just as we would wish for biblical literacy of the Tanakh/Old Testament (and we do recognize that 
these terms do not refer exactly to the same texts). We are all the cultural heirs of this material, from the texts Jews and Christians share (e.g., the creation and flood narratives; the Decalogue) to the New Testament's Sermon on the Mount, Good Samaritan, and Prodigal Son. The Bible, broadly defined, informs art and music, politics and economics, and views of the past and hopes for the future.

For classroom instruction, JANT contributes to discussions of the so-called "historical Jesus" and the "new perspective on Paul." It has the potential also to contribute to the return of the recognition that the New Testament and rabbinic literature are often mutually informative. In the late twentieth century, students of the Bible - sensitized to how rabbinic literature had been misused in the study of Jesus and of the New Testament - pulled away from any use of rabbinic texts. Today, scholars are increasingly both carefully using rabbinic texts to help us understand the New Testament as well as using the New Testament to shed light on rabbinic thought. Thus, instead of Judaism serving only as the background for understanding the New Testament, now the New Testament also serves as a background for reconstructing Jewish history and for informing rabbinic interpretation.

For the purposes of the academy, we also find that JANT opens several questions of sociology. For example: how does the focus on Jesus as a Jew, the recognition that all of Jesus' immediate followers were Jews, and the historical reclamation of Jesus by Jews impact our understanding today of the various forms of Messianic Judaism, from Jews for Jesus to Post-Missionary Messianic Judaism? What contributions does the volume make to those followers of Jesus today who, although they do not identify as "Jewish," maintain Jewish practice, sometimes in imitation of (what they view as) Jesus and his initial Jewish followers? In turn, how might the recognition of Jesus as a Jew who engages in the distinctive practices of his tradition help relatively secularized people or low-church Protestants better understand (and, ideally, appreciate) such traditions as ritual purity, sacrifice, pilgrimage, and communitarian religiosity?

To extend these pedagogical concerns: we do have hopes that students of the New Testament will take the time to read Jewish sources, including early rabbinic works, even if these, in their final form, postdate the New Testament. The move in some Ph.D. programs toward more and more theory (post-colonial, affect theory, deconstruction, ideological criticism, empire studies, so-called social-scientific studies, neurological-cognitive views, memory studies, etc.) and the resulting decrease in time spent with the primary sources of the period, does create some worry that Ph.D. students in New Testament have never seen a copy of the Mishnah, read the books of the Pseudepigrapha, or seen more than a paragraph or two (in translation) from the scrolls found at Qumran.

Finally, we hope this volume will help prevent the "all Jews think this way" or "that way" approach and thus show how Jesus and his followers fit within their very diverse contexts, even as we show some generally consistent views within that spectrum. For example, in some classrooms, although first-century Judaism is presented as diverse, with references made to the classic quartet of "Pharisees, Sadducees, Essenes, and Zealots" (the configuration comes from Josephus, who compares each group to contemporaneous Greek and Roman philosophical parties), the dominant view given the students is of a monolithic, and often moribund, Judaism. JANT shows the Jewish matrix of the New Testament in all its vibrant diversity. 
We have been gratified by the largely positive reception of the book and its use in both the Jewish and the Christian communities as well as in classrooms, where, along with other publications, it has begun to change religious groups' perception of the other and, at times, perceptions of themselves. We did hit 354 on the Amazon site the day the volume was discussed in the New York Times. More recently, on July 31, 2014, The Jewish Annotated New Testament was the second-best selling book in the category "Books $>$ Textbooks $>$ $\underline{\text { Humanities }}>$ Religious Studies > Judaism"; for a long time after it was published, it was number one. Endorsements for the volume have come from Evangelical and liberal Protestants, Mormons, and Roman Catholics, as well as from Jews across the spectrum from the Modern Orthodox to the disaffiliated secularist. As a result of JANT, many Christians have come to realize just how deeply embedded their tradition is in Jewish history, theology, and ethics; many Jews have come to learn of the deep historical connections between what we eventually came to recognize as the Synagogue and the Church. And many learned that the stereotypes they had of the other required correction. These were our overarching social goals in completing this project.

We know from reviews and blog posts, which we cite below, that some of our readers were not at all pleased with the project. We heard early on that many Jews, and not a few Christians, initially perceived the work to be the product of messianic Jews with the goal of bringing Jewish readers to belief in Jesus as lord and savior. On the other hand, we were also forewarned that some Christian readers feared that the volume would challenge or even disparage ecclesial beliefs. Thus the tone of the entire volume is one that treats Christian doctrine with the utmost respect, even as it describes the distinct paths that the majority of the Jewish community and the followers of Jesus eventually chose.

Some Jews felt, and still feel, that the New Testament is fundamentally treyf, and any treatment of the New Testament by Jews is wrong-headed. We were not surprised, although nevertheless disappointed, when one of the first reviews on Amazon, likely written by someone who did not read the book, was titled "Evil." It was penned by "A Jew for Judaism" - a play, we believe, on "Jews for Jesus." The reviewer was crass, though to the point: "It is evil for Christians to try to convert Jews with this dreck. Why don't you people leave us in peace?" This misinformed writer did not realize that the book was written by Jews, in part for Jews. A more recent similar review by "Asher," who identifies in his profile as Jewish (though also as a former Christian and a former pagan), is titled "misleading" and notes, "The Christian NT has nothing to do with Judaism nor Jewish beliefs. Both religions lead to Gd but are separate and incompatible. Continuing to deny that and attempts to 'Judaize' the NT are intentionally misleading[.]" We tried to combat such views in the volume by making accessible the main scholarly consensus about the New Testament and Judaism: many of its authors perceived themselves and were perceived by others as Jewish; the religion of Jesus and his early followers such as Peter, James, and Mary Magdalene was one of the many forms of Judaism that existed in the first century C.E.

Similar critical attitudes also appeared on the Christian blogs. One of the earliest comments that appeared about the book, from a Carmelite blogger on a conservative Catholic blog, read: "Without having read it, and I can guarantee you I never will, I would guess it's a new bold attempt by the Rabbinic Talmudists to undermine the Faith. They are 
convinced that Trinitarianism, of which the Church is obviously the bulwark, is a blasphemy which must be destroyed and will stop at nothing." Coming from a Catholic, this view was particularly disheartening, given the import the Vatican, the US Conference of Catholic Bishops, and other Catholic organizations have placed on Jewish-Catholic dialogue, the Jewish roots of the Christian faith, and the Jewishness of Jesus.

The same website contains the following comment: "Judaizers will always be around until the end of time. Watch out for them." It is quite strange for us to imagine ourselves as either "Judaizers" or "Rabbinic Talmudists." The former group are, technically, members of the Church who continue to follow Jewish practice, such as circumcision, dietary regulations, Jewish holidays, etc.; the latter is a phrase anachronistic for both the time of Jesus and our own time.

Much more frightening was the blog post titled "Jew Creeps Using the New Testament: Christian Brainwashing by Jews." 2 The first paragraph states: "Do these creeps ever leave anything untouched? Must they worm themselves into every facet of White people's lives? Nothing is off limits to the Jew!" The author makes one correct statement in the entire ranting post: "The book is NOT to convert Jews, but to push the 'Jesus was Jewish' bit on American Christians." This to him is impossible, since most Jews are descended from the Khazars, a myth that has circulated widely, and lately in an attempt to minimize Jewish presence in the ancient world. (Shaul Stamper has recently debunked this myth and its modern uses. ${ }^{3}$ )

Although this quote came from a white supremacist blog, reflecting a minority of the American population, it received some traction in the US and abroad; indeed, on July 31 , 2014, it contained a comment from "Dan in Taiwan" who asked, "What did St. Hitler do to pull Germany out of poverty and despair? Perhaps we can use his ideas as a model." It is doubtful that JANT can change the mind of anyone with such views, though it is very important, for the sake of a civil and civilized society, to think about what it could do. The very reactions we list here testify to the continued importance of JANT; perhaps, were homilists and Sunday school teachers better informed about Jesus and Paul's Jewish context, they would be less likely to inculcate anti-Jewish views that then surface on such websites. Perhaps people in churches who were aware of this context would be more likely to condemn such racist, anti-Jewish postings.

Despite the occasional bigoted or ignorant review, the response to JANT has been overwhelmingly positive. Many ministers and priests have told us that it is now their "goto" volume as they prepare sermons. The book is being increasingly assigned in divinity school and seminary classrooms, given its attention both to historical context and to its noting of where Christian exegesis and homiletics, unaware of Jewish history, theology, and practice, lead to false witness against Jews and Judaism.

Even more striking to us is the penetration of the volume into the Jewish public. We know of many study-groups throughout the world where Jews are working together, sometimes in hevruta style, to read the New Testament with the annotations JANT provides. This is sometimes their first and only Bible study group. Instead of reading the Tanakh, they have opted to read the New Testament, albeit a version with "Jewish" notes.

\footnotetext{
${ }^{1}$ See http://catholicforum.fisheaters.com/index.php?topic=3444433.0

${ }^{2}$ See http://incogman.net/2012/02/jew-creeps-using-the-new-testament/

${ }^{3}$ See e.g. http://new.huji.ac.il/en/article/22007
} 
We will leave to sociologists, and perhaps to scholars of the failure of Jewish education, to explain in more detail why reading the New Testament is more attractive to some committed Jews than reading the Tanakh.

The success of The Jewish Study Bible has spurred us to produce a new edition of JANT, which we anticipate to be published in 2017. In the second edition, we plan to address several concerns readers had with the first edition (yes, we know the print in the first edition is too small; that is the first issue to be rectified). For example, many Jews (and not a small number of Christian readers) commented to us that they did not fully understand basic issues - for example: they did not recognize the genres of "gospel" and "epistle"; they did not know how the gospels are related - general issues that are covered in any introductory New Testament textbook.

The tone of the new edition will stay the same, and we will continue to respect the needs of Jews interested in Christianity as well as of Christians interested in Judaism. We will also keep in mind that $J A N T$ is also used as a textbook for many college, university, and seminary courses.

JANT has, by numerous reports, strengthened the knowledge Jews and Christians have of their intertwined history; it has enhanced the classroom experience by giving students various new perspectives - not only historical, but also theological, ethical, and sociological - on the New Testament; it has led to new interreligious dialogues. This is all to the good. 